Published in: Fetzer, Anita/Meierkord, Christiane (eds.): Rethinking sequentiality. Linguistics meets conversational interaction. - Amsterdam/Philadelphia: Benjamins, 2002. p. 231-248. (Pragmatics \& Beyond New Series 103)

\title{
Argumentative sequencing and its interactional variation ${ }^{1}$
}

\author{
Thomas Spranz-Fogasy
}

Institute for the German Language (IDS), Mannheim, Germany

\section{Introduction}

Dealing with argumentation in natural conversation is difficult. In everyday language we use very different meanings for terms like arguing, argument or argumentation. Whereas sometimes an argument may refer to a set of logically related assertions, at other times it may refer to a single assertion uttered incidentally. The terminology also varies within the sciences and even within the same discipline. ${ }^{2}$ Indeed arguing for teminological unity would be pointless because arguing exhibits a variety of functions, thereby necessitating numerous meanings of it. It is a well known fact that even in everyday argumentation interactants often utilize technical terms themselves - e.g., by pointing out this or that would not be 'an argument', or someone's 'argument lacks objectivity', or someone 'argues unfair' - and for that reason a variety of meanings is both useful and functional.

In the following sections some research on argumentation in conversational analysis will be presented, with special emphasis given to the identification of argumentation in natural conversation, its sequencing structure, and its interactional variation. The considerations are part of a broader study of conversational rhetorics in problem and conflict interaction conducted at the Institute for German Language (IDS) in Mannheim. ${ }^{3}$ The main goal of this study is the analysis and description of interactive practices under a functional rhetorical perspective which is derived from an ethnomethodological approach to the study of conversation. Ethnomethodologists have so far mainly looked at the organizational order of interaction; conversational rhetorics also investigates forms of interactive influence and interactive effects of the participants' inter- 
active work, e.g. gaining acceptance, or silencing another speech partner. The focus thereby is whether the rhetorical impact stems from the organizational interactional constraints for establishing conversation and conversational argumentation themselves, and not only from semantic or pragmatic procedures. For example, interactants use the requests of turn taking and sequencing to force their partners' utterances in a way they want them to react. Argumentation as a whole then is a particular rhetorical procedure wherein some other procedures of minor order may operate as e.g. 'demonstrating consistency', 'denying relevance', 'denying competence', or 'appealing to normativity.'

Argumentation is described here as an interactively organized sequence. The structure of that sequence makes it possible on the one hand to expand it extensively, and on the other hand to reduce by means of inferential contextual cues. The variability of the argumentative sequence then is one of the reasons which makes up its rhetorical power; sequencing therefore is not only an organizational function but a rhetorical too.

The data of this study consists of 60 problem and conflict conversations from the IDS corpora: authentic counsellings, mediation talks, discussions, and even disputations of couples or in families, and also talk shows from TV. They are both private conversations and conversations in public institutions. The data thus provide for a wide range of types of interaction where argumentation occurs.

\section{Background research}

Argumentation is a widespread procedure in the Western culture for clarifying unclear or controversial matters. After more than two thousand years of logical, normative or topological research we can now look at interactive aspects of argumentation too. This is due to the pragmatic turn of argumentation research by Toulmin (1958) and Perelman and Olbrechts-Tyteca (1958; see also Perelman 1980), where the focus of analyses changes from formal logic to the "uses of argument" (Toulmin 1958) and argumentation in natural contexts. ${ }^{5}$ Despite the body of research there is still a striking lack of empirical research on argumentation concerning argumentation in natural conversation. The reason for this is obvious. Identification of argumentation is already difficult: Where does it begin and where does it end? And it is difficult to determine the internal structures of argumentation. What are the necessary steps of argumentation and what is their sequential organization format? In natural conversation, ar- 
gumentation is often only indicated or is sometimes even hidden strategically by the participants.

Two researchers who have dealt with argumentation in natural conversation are Jackson and Jacobs (see Jackson \& Jacobs 1980; Jacobs \& Jackson 1982, 1989). In an ethnomethodological approach they identify an argument as a specific expansion of adjacency pairs.

The expansion may occur either as a presequence (i.e. placed before an adjacency pair to prepare it or otherwise to make it superfluous); or as a turninternal expansion (i.e. within one turn of the adjacency pair); or the expansion is an insertion sequence (i.e. between the two steps of the pair); or a postsequence (i.e. following an adjacency pair). ${ }^{6}$

In the view of Jackson and Jacobs argumentative expansions are triggered by disagreement. Argumentation therefore is a "disagreement relevant speech event" (Jackson \& Jacobs 1980:254) which is related functionally to the projection, production and resolution of such a disagreement. The concept of "disagreement" is then tied to the pragmatic concepts of the conversational maxims of Grice (Grice 1975) and the felicity conditions of Searle (Searle 1969), which means that some of these maxims or conditions are perhaps not accomplished and this lack of accomplishment creates disagreement which needs to be clarified argumentatively. This concept of argumentation is strictly related to single speech acts; the broader context is neglected. ${ }^{7}$

Jackson and Jacobs conceptualize argumentative utterances in a microanalytic manner by identifying the sequential properties of verbal activities. Argumentation is seen as established by activities which signal and display disagreement and is - in an ideal sense - terminated by that activity which is set conditionally relevant. ${ }^{8}$ The sequential order then is e.g. 'question (with implications of disagreement in the partner's view) - argumentation - answer'.

Most of the other authors, however, argue from a semantic point of view. They postulate dissent or uncertainty as starting points for conversational argumentation. The termination then depends on an agreement of the interactants to one position, negotiating a compromise, breaking off the argumentation, or even breaking off the interaction itself. A precise definition of the empirical conversational phenomenon of argumentation, therefore, remains insufficient as are other kinds of some lexical or semanto-pragmatical definitions, e.g. causal conjunctions, fall short as an adequate definition for argumentation. 


\section{A conversational rhetorical perspective on argumentation}

From a conversational rhetorical perspective argumentation is defined with the aid of organizational features which are necessary for the establishment of interaction. In order to describe a wide range of rhetorical practices we therefore take into account various dimensions of interaction that have been identified by Werner Kallmeyer and Fritz Schütze in a theory of interaction construction (see Kallmeyer \& Schütze 1976; Kallmeyer 1988; Spranz-Fogasy 1997:27ff). According to this theory, interactants have to carry out their conversation by simultaneously dealing with different levels of interactional organization:

- the organizational structure of talk, e.g. the exchange of turns;

- the thematical organization, where features of presentation like storytelling, description, etc. are established;

- the activity organization, where single and complex activities are typified (as e.g. an assertion or a counselling conversation);

- the interactive construction of identities and partner relationships, where social roles (mother or daughter, doctor or patient) or social relationships (friendship, antagonism) will be defined;

- the dimension of interactive modalities, where modes such as seriousness or play are organized;

- the establishment of reciprocity, where mutual understanding is ensured.

The efforts to establish these interactional dimensions are always tied to the likelihood for the achievement of the speaker's own goals and the risks to block the partners' goals. Procedures for forcing or supporting partners (e.g. concerning their rights and obligations of participation) have been identified on the level of organizational structure and modality organization (Kallmeyer \& Schmitt 1996; Schmitt 1997). In addition the procedures of social positioning on the level of the interactive construction of identities and partner relationships have been revealed (Wolf 1999). Or procedures for establishing or blocking perspectives on the level where reciprocity is established have been identified (Keim 1996). In this way the procedures for supporting one's own partner or for forcing an action by the partner become evident on the level of the organizational structure and the interactional modalities. 


\section{Contextual implementation of argumentation}

Interactants begin an argumentation when their thematic exchange encounters a deficit, i.e. an utterance becomes unclear or controversial. ${ }^{9}$ The pursuit of their conversational goals becomes blocked. The result is that a problem presentation becomes misunderstandable, a conflict proposal will be rejected, and so on. In other words, the practical validity of an utterance, its mutual interactive ratification is put in question and practical validity has to be established or re-established for the purpose of further achieving common interactional goals. The partners therefore have to explain and give reasons for establishing or re-establishing a common view, i.e. a mutual understanding sufficient for their interactive goals. Typical kinds of deficits include dissent or uncertainty. Argumentation, then, is an interactive pattern for explaining a position and for locally clarifying the deficit and for then integrating the result into the 'normal' course of the current interaction for further comprehensive conversational work. Formally characterized, argumentation has a three-part structure, consisting of initiating, carrying out and reintegrating.

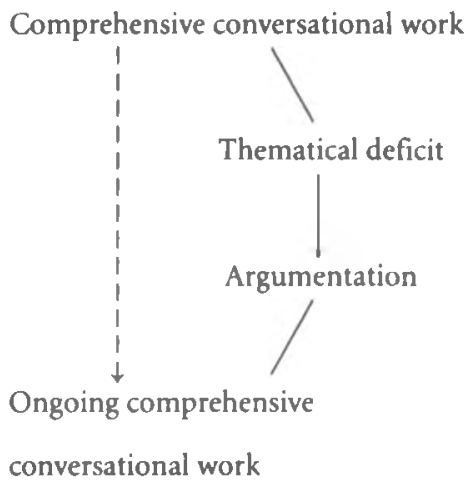

Figure 1.

Such a procedure makes sense for an interactional logic too, in fact it is even necessary for conversation itself: Both, differences between the interactants and lack of knowledge about facts inevitably generate uncertainty or dissent which has to be resolved. Therefore there has to be a procedure at work which enables for the conversationalists a common clearing locally with reference to comprehensive interactional goals. Obviously there are other practices for the solution of such an interactive blockade: interactants may use storytelling, they define the blockade as a misunderstanding, or they postpone or even ignore the 
problem. In contrast the argumentation procedure stands out by giving reasons and explanations for the problematic position sufficiently until further notice. Giving reasons and explanations is necessary up to the point where the interactants may together pursue their general interactive goals which have been interrupted by the necessity to argue. Hence, triggering a sequence of turns and incorporating the interactively negotiated result of the argumentation sequence in a 'normal', unproblematic flow of utterances mark the boundaries of argumentation in natural conversations.

The interactive practice called argumentation therefore has an external organizational frame, which initially establishes a clear delimitation concerning other activities. And it gains a projective constraint for coming to an end by virtue of the superordinate interactive goals. For the interactants this facilitates the orientation in the current conversation and makes it possible for them to concentrate on the topics they are dealing with.

\section{The internal structure of the argumentation sequence}

Argumentation does not only possess the external structure discussed above, it also exhibits an internal structure which guarantees the performance of the argumentation itself. An example for a simple realization of this argumentation sequence is shown in the following segment from a mediation talk on insults, damage to property, and bodily harm: ${ }^{10}$

(1) C: so " äh isch glaub den vorfall ham=ma je"tzt so weit er aufzuklären war hie" $r$ mit meinen bescheidenen mitteln glaub isch habe mer=n aufgeklärt

'well * ehm I think the incident is clear now as far as it was possible to settle it here with my limited means I think we've solved it'

1 dass also " * sie sich in de vergangenheit * solang sie zusammen im gleiche haus gewohnt habe net grad be"stens vertragen haben

'in the past when you lived together in one house you did not get along with each other'

2 B2: nee des war nu" $r$ die letzte * des letzte jahr 'no this was just the case in the last year we lived together'

3 B2: mir habe ja vorher *äh parterre gewohnt 'my husband and I used to live on the ground floor' 
4 C: jaja okay * gut in ordnung frau neumeier

'yes okay * that's okay mrs neumeier'

5 Bl: darf isch ihne * hier grad zu ah zu den ausführungen $v / v / *$

vum herrn beck grademal

'may I say something else concerning the comments of mister beck my adversary'

B2: dass mir um dieses geschprach gebete (...) [...]

'that we wanted a discussion to talk things out [...]'

Following the contrary presentation of the conflict parties, the mediator $\mathrm{C}$ tries a more general conflict definition (step 1: in the past when you lived together in one house you did not get along with each other), the wife B2 of the accused man B1 contradicts (step 2: no this was just the case in the last year we lived together) and gives a reason referring to spatial conditions of neighbourhood (step 3: my husband and I used to live on the ground floor; i.e. there were clashes only during the one year when the apartments of the opposing parties were on the same floor) the mediator $\mathrm{C}$ accepts that contradiction (step 4: yes okay * that's okay mrs neumeier) whereas the accused $B 1$ realizes further activities, which all participants deal with then, and which is therefore a ratification via continuation (step 5: may I say something else concerning the presentation of mr. beck my adversary). This is a - rather seldomly performed - clear case with an ideal succession of the elements of the argumentation sequence. Empirically, this sequence is most often realized in a more complicated fashion by insertion of other activities, e.g., insisting acts (see below).

The prototypical argumentative sequence therefore consists of the following steps:

1. triggering

2. marking dissent or problematization

3. presenting new explanatory information

4. acceptance

5. ratification

Steps 1 and 2 are performed by different speakers as steps 4 and 5 too; step 4 also has to be performed by a different speaker than step 3 .

Obviously empirically there are often other reactions than acceptance and ratification, for example insisting acts, postponing acts or even an agreement on disagreement; reactions which also render possible the return to the superordinate interactive goals. But the sequential structure presented here is 
the prototypical one, around which interactants orient themselves explicitly or implicitly.

\section{Variations of the argumentation sequence}

The argumentation sequence is very powerful and extremely variable in terms of this basic sequence format. Conversationalists may expand it as far as they want, or compress it to a minimalistic activity.

\section{Expansion features of argumentation}

Expansion of an argumentation sequence may be achieved in two ways depending on how sequences are arranged in the interaction. Expansion may be achieved by stringing together or chaining two or more argumentation sequences in a serial manner, or by inserting insisting acts to mark dissent or problems, or by inserting additional acts that provide reasons or justifications.

\section{Insertion}

An argumentation sequence can be expanded by multiple insertions of argumentation sequences, thereby intensifying the branching of the interaction. Such branchings or embeddings are regularly tied in a contradicting or contrasting manner to the material of prior steps 2 (marking dissent) or 3 (presenting new explicative information). ${ }^{11}$ Such expansions of the argumentation sequence sometimes provide interactional problems: In general, along with insertion the danger of marginalization or dissociation of topics comes up, as well as friction in the interpersonal relationship by the face threatening effect of iterative critic.

A very simple example for the inserted sequence is the following one, which is taken from another mediation talk on injuries ( $A$ is the plaintiff, $B$ the accused, and $\mathrm{C}$ the mediator; the empirical data is reduced to the relevant features here).

(2) 1 A: des hot sie a"lles gsa"cht a"lles die na"chbarschaft hot a"lles ghe "rt i"sch hab zeu"ge 'she told everything everything the neighbors heard everything I have witnesses'

2 B: nein des is nischt wahr 'no that's not true' 
3 A: die frau müller war vor ihrm fenschter ja die hot alles gehert 'mrs müller stood at her window she heard that everything'

4 B: die frau müller hot erscht zum schluss * des fenschter uffgemacht 'mrs müller didn't open the window until the end of our dispute'

5 A: ja die hot=s awer innedrin gehert sie ware jo devo" $r$ geschdanne 'well but she heard it from inside you stood directly in front of her window'

6 C: frau beck mir halde=s hier so äns nach em annere mir känne zusamme si" "nge awwer mir känne net zusammen re:de" $n$ 'mrs beck we want to take turns speaking * we might be able to sing together but we can't talk together at the same time.'

$7 \mathrm{~A}: \mathrm{ja}^{*}$ awer nit abstreite un mi"sch als lügnerin [...] 'okay * but she should not contradict and call me as a liar [... ]'

Mrs. A states at the beginning that the accused B mentioned all the injuries A has listed before (utterance (1)) and she says that she is able to verify this with the help of witnesses (utterance (1) and (3)). B contradicts (utterance (2)) and a dispute arises then, where both of them tie their objection to the objection of the other party (utterances (4) to (5)). The mediator $C$ tries in vain to calm the dispute down (utterance (6)) and - after A's renewed objection (utterance (7)) - terminates it, by which a new round of argumentation begins. Utterances (1) to (3) correspond with the first three steps of the argumentation sequence whereas utterances (4) and (5) both operate as step 2, respectively marking dissent with the referred utterance in an inserting manner.

\section{Serialization}

Another way of building up complex argumentation conversationally is to chain two or more argumentation sequences after another. In this way the different positions of the two parties who are arguing become dismantled into single aspects. After having considered one aspect, another aspect is addressed or re-addressed and is dealt with through argument.

In the same mediation talk cited above the mediator tries to find a commonly accepted conflict definition by which he hopes to get a starting point for a conflict resolution. While doing this contributions are regularly interrupted by objections from the plaintiff $\mathrm{A}$ (utterances (1) to (3); the transcription is given in a reduced version again): 
(3) C: also äns steht fescht dass=der streit ghabt habt ne do herrscht kän zweifel dra 'ok, it is true that you had a quarrel there is no doubt about'

1 A: isch hab kä" $n$ streit mit der fra ghabt sie hot misch beleidischt so is $=e$ s

'I had no quarrel with that woman * she did insult me that's it'

C: also disput war uff alle fäll frau beck des steht eindeutisch fescht * net * do gibt=s also * nix dran zu rüddeln * äh un die frau kraft gibt ja auch einen teil ${ }^{*}$ der beleidigungen ${ }^{*} z$ u: sie räumt allerdings ein * dass auch sie" sie beleidischt hawwe 'there was dispute for sure mrs beck and mrs kraft admits the insults partially but she also claims that you insulted her too'

2 A: isch ha" $b$ sie net beleidischt isch kumm jo gar net dazu vor lauter die hot jo so ruffgeschrie mit erhobenen finger als wenn isch $e$ schulkind war

'I didn't insult her I didn't have a chance to insult her because she yelled so loud and wagged her finger at me as if I was in school'

C: awwer jetz ${ }^{*}$ jetz ${ }^{*}$ is awwer mol folgendes ihr wohnt jo haus an haus newerenanner ihr seht eisch jo im grund jeden * tag "but now is the following situation * you live in houses next door to each other you see each other every day'

3 A: isch seh se üwwerhaupt nie selde höschens im summer we=ma im * wenn se in de garde geht

'I do not see her at all * once in a while in the summer when she goes out in the yard'

C: ah ja: awwer irgendwo/ irgendwo sin jo doch berührungspunkt 'well okay but somewhere somehow you two bump into each other'

Utterances (1) to (3) particularly operate as step 2 of the argumentation sequence but every time with a new thematical focus established by the mediator $\mathrm{C}$. The new thematical focus therefore establishes a new initial position of an argumentation sequence.

Both structurally provided forms of expansion, the insertion and the serialization, are empirically often combined. 


\section{Compressed argumentation}

In addition to expansion of an argument sequence, there is also a possibility to compress the sequence. With that, there is a possibility just to indicate argumentation, a possibility to avoid dissent in anticipation, or even a possibility not to burden the interpersonal relationship. An interactional requirement for such a compressed argumentation stems from the interactants' different knowledge, their different interests, or from the fundamental indexicality of verbal expressions. ${ }^{12}$ The ability to anticipate dissent or uncertainty provides for preceding reasoning - without an explicit dissent marking utterance or problematization. Such compressed argumentation is also based on the organizational structure of the simple argumentation sequence presented above. Although some of the steps of the argumentation sequence are not fully realized, all the relevant components can be reconstructed exactly in the context of the realized components (and this is true not only for the analyst but for the interactants themselves as well). The anticipation or the imagination of an objection is treated then as a dissent marker or as a complication, and the speaker presents his position in a contrasting manner. Only the contrasting manner indicates that there is an objection or a contradiction just assumed by the speaker. Acceptance will be demanded then or just assumed, and the ratification act is taken for granted. This is the way that all turn-internally placed reasonings operate.

Compressed argumentation differentiates in two significant ways according to its interactive functioning: On the one hand avoidance may be exhibited by the speaker and on the other hand an offering may be made. Avoiding means that one party to the argument gives a reason for his utterances but wishes to imply that it is not negotiable, e.g. by encapsulating it in a long utterance with particular sequential relevance at the end of the utterance. At other times he may even state his point of view explicitly as not negotiable, e.g. by saying 'I won't discuss that now!'. An example from a counselling interaction on AIDS illustrates the avoidance strategy. The reduced version of the interactions is given here:

(4) 1 R: ja ich kann da noch überhaupt noch nich mit ich weiß überhaupt nich dass es für mich/ was es für mich bedeutet un * ja ich merk einfach auch dass ich angst krieg [...] manchmal schnürts mir einfach die luft $a b$

'I do not know how to handle with * I do not know what it means to me when I get scared [...] sometimes I couldn't breath at all' 
2a/b B: also dieses *äh positiv sein womöglich auch schon "krank ich mein des is ja ${ }^{*}$ jetz noch nich sicher die ${ }^{*} d / d /$ äh muss $j a{ }^{*}$ denk ich erst vom arzt noch abgeklärt werden * äh des * is ja ne sache die * gar nich im zusammenhang stehen muss jetz also des *äh des positive testergebnis * is ja noch * überhaupt keine * äh aussage darüber ob jetz * die krankheit schon vorhanden is ne positiv sein heißt nicht dass * aids ${ }^{*}$ rank * äh äh jemand is ${ }^{*} s=i$ emal $=n$ status * vorläufig

2a B: 'well your being positive or even ill/I mean * it is not even certain and has to be diagnosed by your doctor ${ }^{*} \mathrm{ehm}$ * there doesn't have to be a connection * '

$2 \mathrm{~b} \quad$ 'you know a positive test does not mean that you've got aids it is just a provisional state'

3a/b R: ja aber * jetz kommen so die * die anzeichen die ersten sachen * wo ${ }^{*}$ mein arzt mir eben gesacht hat ${ }^{*}$ das sind alles begleiterscheinungen und * ja ich ich weiß auch * also ich will da mit andern leuten drüber reden die ${ }^{*}$ auch betroffen sind weil ich denke da wird ich besser verstanden

3a R: 'well but the first signs are those where my doctor told me they are all related symptoms * I know too/ *"

3b 'well I just want to talk about it with others who are also infected because I think they have a better understanding'

4 B: sicherlich *äh das * gedankenaustausch mit betroffenen $a h^{*}$ is auf alle fälle gut 'certainly you are right * ehm * an exchange of ideas with persons who are also infected is good in any case'

The client $(\mathrm{R})$ here first formulates his fear of his HIV-infection ((1): I do not know how to handle with ${ }^{*}$ I do not know what it means to me when I get scared [...] sometimes I couldn't breath at all). The counsellor responds but downplays the possibility of an AIDS disease, and gives a reason ((2a): well your being positive or even ill/ I mean * it is not even certain and has to be diagnosed by your doctor * ehm * there doesn't have to be a connection). Before relinquishing the turn to his partner he states definitely that HIV-infection does not mean the AIDS-disease itself; by putting this statement in the last position of the turn-serialization he demands his partner's ratification or even acceptance of that statement first. In this way he pushes his argument to the background ((2b): you know a positive test does not mean that you've got aids it is just a provisional state). But $\mathrm{R}$ rejects the statement and refers to his doctor 
as a competent authority ( $(3 \mathrm{a})$ : well but the first signs are those where my doctor told me they are all related symptoms * I know too/). Then he immediately downplays the open dissent and renews a prior request ( $(3 \mathrm{~b})$ : well I just want to talk about it with others who are also infected because I think they have a better understanding). R's rejection therefore is encapsulated in the same way as is his reference to competence. Actually B deals in the following statement with the renewed request and does not insist on his prior statement ((4): certainly you are right ${ }^{*}$ ehm ${ }^{*}$ an exchange of ideas with persons who are also infected is good in any case).

The manner of offering compressed argumentation explicitly or implicitly offers a verbal reason as a questionable one for interactive negotiation (by saying e.g. 'we have to discuss it'). In the following extract from another mediation talk on verbal insults the accused denies having used any insulting expressions. The mediator concedes that 'as a rule' but characterizes the incriminated incident as an 'exceptional situation'. By doing so he substantiates in anticipation why rejection may be critical for the accused: there were witnesses who can substantiate the plaintiff's statement. The relevant steps of the argumentation sequence are realized in this compressed manner and are offered to the accused for further discussion:

(5) B: solche solche wörter-gebrauche ich nicht 'I don't use expressions like that'

C: ich nehme ihnen $a b$ daß sie die nischt gebrau"chen im regelfall * a:ber * äh in einer ausnah:mesituation herr kreuzer könnte des doch durschaus mal sei" $n$ * $u n$ * ah * hie" $r$ " is ja die * der antragssteller * in einer etwas besseren lage ihnen gegenüber indem er nämlisch einen zeu" gen aufbieten kann

'I believe that you do not use such expression as a rule but isn't it possible * in an exceptional situation mister kreuzer * that this could be * and * ehm * here the plaintiff is in a slightly better position because he has a witness'

The reference to an 'exceptional situation' can be seen as marking dissent to the rejection of the accusation whereas the mediator's reference to witnesses may be regarded as an explication in the sense of step 3 of the argumentation sequence. The accused now has to deal with this unfavorable matter. But he simply rejects the validity of the assertion stated by the mediator and by that the validity of the accusation too, for which he himself offers an explanation of his own stating that it is 'pure insinuation': 
(6) B: ja * sie wissen ja auch was das ich ihnen geschrieben habe * äh daß erstens gar kein zeuge da war und ich darauf besteh daß es eine reine unterstellung ist von dem herrn ${ }^{*}$ heinzel

'well * you also know what I wrote * ehm that there was no witness there at all and that $I$ insist that it is a pure insinuation by mister heinzel'

The accused therefore rejects negotiation of the mediator's explicative offer (see C's utterance in example 5). In the following section the mediator tries to prove contradictions in the presentation of the accused as a more competitive strategy.

Expansion and compression are frequently combined in different forms. With these formats a complementary and very variable and process-sensitive potential for complex argumentation is given which provides for the establishment and the solution of argumentation in different contexts.

\section{Summary}

Argumentation is shown here as an interactional resource of interactants in conversations. Interactants may leave their main interactive goals for a short time or even longer by implementing an argumentation sequence. Within this sequence and by means of the organizational structure they are able to cope with their problem of understanding, and return again to the previous level of interaction. This is due to the implementation format and the internal structuring of the argumentation sequence which provides a comprehensive projection by its organizational constraints.

Interactants gain interactive control by that procedure because it is bound to the comprehensive goals, and it is maximally flexible through expansion or compression of the sequence. Interactants may use minimal activities, or expand an argument at length without losing the thread of the interaction. Argumentation, therefore, is enacted in a range from a single parenthesis to hours of discussion. All of this makes argumentation a highly practicable procedure and this may explain its frequency, its dissemination in different contexts and types of interaction, and last but not least its high acknowledgment in the Western conversational culture. ${ }^{13}$

Sequentiality, as it is shown for argumentation here, therefore, is not only a merely formal organizational structure. It provides for resources for the production of utterances and for mutual reference of the partners with a lot of 
rhetorical implications. The rhetorical implications of the argumentation sequence are enormous: initiators of argumentation provide space for presenting their position, which conversely forces their partners to argue too. But there are also risks. For example, the partner's position may ultimately result in success. One must also bear the following in mind when considering argumentation sequences: there is no truth in an interaction besides what partners define as true - and for that negotiation, argumentation as well as its sequencing, and its interactional variation are very powerful instruments.

\section{Notes}

1. I wish to thank Sara Smith (California State University) and Tom Lovik (Michigan State University) for their comments and their help with the translation.

2. See for example Klein (1981) who defines, an argument as a number of assertions connected in a certain ('logical') way' (p. 226; all translations from the author); otherwise Kienpointner (1996) says anargument is a reason given for or against a hypothesis' (p. 75).

3. See Kallmeyer 1996; Keim 1996, 1999, i.pr., Schmitt 1997; Wolf 1999; Spranz-Fogasy i.pr. and Spranz-Fogasy 2002.

4. These procedures are described in Spranz-Fogasy 1999 und Spranz-Fogasy 2002. They are derived from argumentative criteria, whose relevance the interactants themselves determine within their argumentative utterances.

5. For an overview see Pander Maat 1984 and Nussbaumer 1995; for the pragma-dialectic approach of the Amsterdam school see Eemeren et al. 1993.

6. For these expansion formats see Jefferson 1972 and Jefferson \& Schenkein 1978.

7. In later articles (e.g. in Jacobs et al. 1991) they both postulate the interrelationship of argumentation and the comprehensive conversational work, but do not analyze it empirically. And it must be stated that, by tying argumentation to the Gricean conversational maxims and the felicity conditions of Searle, they develop a normativistic view on argumentation and thereby dissolve the prior strict sequential approach (see Jacobs 1999).

8. For the concept of conditional relevance see Schegloff \& Sacks 1973. Conditional relevance means the kind of projection or provisional structuring of an verbal activity by the previous activity: Enacting a particular type of an activity sets a following activity relevant and makes it expectable. Typical examples are adjacency pairs such as question-answer.

9. More general definitions of interactional argumentation deal with just giving a reason' without reference to any kind of interactive incident. But in an interactional point of view accounts as argumentations or e.g. narratives always deal with deficits at least in the sense of uncertainties (see Kallmeyer \& Schutze 1977).

10. The transcript is fully printed in Schroder (1995). Translations of the transcripts are from the author; they are rough translations with the focus on the argumentative aspects. 
11. Sometimes even acceptance or ratification also cause a further insertion as the following scene from a TV discussion between two German politicians, the late physicist Robert Jungk and the former minister of defense Rupert Scholz, demonstrates. Scholz demands consensus and Jungk nods to the demand. Scholz then states consensus but Jungk denies: no I do not have any consensus with you (nein ich hab mit ihnen überhau"pt keinen konsens)(12.2.1991, N3: Alex. Das aktuelle Kulturstudio).

12. For the concept of indexicality see Garfinkel \& Sacks 1976, Patzelt 1987. Indexicality is seen as an unavoidable quality of the meaning of verbal expressions to depend on the given context.

13. Argumentation is one of the most examined communication forms of the Western world, as to be seen in the amount of writings of Aristoteles (e.g. 1952, 1980), Toulmin (1958), Perelman (1980), or the Amsterdam School of Pragma-dialectics (Eemeren et al. 1993) etc.

\section{References}

Aristoteles. (1952). Topik. Paderborn: Schöningh.

Aristoteles. (1980). Rhetorik. München: Fink.

Eemeren, F. van, Grootendorst, R., Jackson, S., \& Jacobs, S. (1993). Reconstructing Argumentative Discourse. Tuscaloosa, Al: The Univ. of Alabama Press.

Garfinkel, H., \& Sacks, H. (1976). Uber formale Strukturen praktischer Handlungen. In E. Weingarten, F. Sack \& J. Schenkein (Eds.), Ethnomethodologie: Beiträge zu einer Soziologie des Alltagshandelns (pp. 130-176). Frankfurt a.M.: Suhrkamp.

Grice, H. P. (1975). Logic and conversation. In P. Cole \& J. Morgan (Eds.), Syntax and Semantics, Vol. 3: Speech Acts (pp. 41-58). New York: Academic Press.

Jackson, S., \& Jacobs, S. (1980). Structure of conversational argument: Pragmatic bases for the enthymeme. The Quarterly Journal of Speech, 66, 251-265.

Jacobs, S. (1999). Argumentation as normative pragmatics. In F. van Eemeren, R. Grootendorst, J. A. Blair \& C. A. Willard (Eds.), Proceedings of the Fourth International Conference of the International Society for the Study of Argumentation (University of Amsterdam, July 16-19, 1998) (pp. 397-403). Amsterdam: SicSat.

Jacobs, S., \& Jackson, S. (1982). Conversational argument: A discourse analytic approach. In J. R. Cox \& C. A. Willard (Eds.), Advances in Argumentation Theory and Research (pp. 205-237). Carbondale, IL.: Southern Illinois Univ. Press.

Jacobs, S., \& Jackson, S. (1989). Building a model of conversational argument. In B. Dervin, L. Grossberg, D. J. O'Keefe \& E. Wartella (Eds.), Rethinking Communication, Vol. 2 (pp. 153-171). Newbury Parks, CA.: Sage.

Jacobs, S., Jackson, S., Stearns, S., \& Hall, B. (1991). Digressions in argumentative discourse: Multiple goals, standing concerns, and implicatures. In K. Tracy (Ed.), Understanding Face-to-Face Interaction (pp. 43-62). Hillsdale, NJ: Lawrence Erlbaum Associates.

Jefferson, G. (1972). Side sequences. In D. Sudnow (Ed.), Studies in Social Interaction (pp. 294-338). New York: Free Press. 
Jefferson, G., \& Schenkein, J. (1978). Some sequential negotiations in conversations: Unexpanded and expanded action sequences. In J. Schenkein (Ed.), Studies in the Organization of Conversational Interaction (pp. 160-163). New York: Academic Press.

Kallmeyer, W. (1988). Konversationsanalytische Beschreibung. In U. Ammon, N. Dittmar \& K. Mattheier (Eds.), Soziolinguistik. 2.Halbband (pp. 1095-1 108). Berlin: de Gruyter.

Kallmeyer, W. (1996). Gesprächsrhetorik. Rhetorische Verfahren im Gesprächsprozess. Tübingen: Narr.

Kallmeyer, W., \& Schmitt, R. (1996). Forcieren oder: Die verschärfte Gangart. In W. Kallmeyer (Ed.), Gesprächsrhetorik. Rhetorische Verfahren im Gesprächsprozess (pp. 19118). Tübingen: Narr.

Kallmeyer, W., \& Schütze, F. (1976). Konversationsanalyse. Studium Linguistik, 1, 1-28.

Kallmeyer, W., \& Schütze, F. (1977). Zur Konstitution von Kommunikationsschemata der Sachverhaltsdarstellung. Exemplifiziert am Beispiel von Erzählungen und Beschreibungen. In D. Wegner (Ed.), Gesprächsanalysen. Referate der IPK-Tagung 1976 (pp. 159-274). Hamburg: Buske.

Keim, I. (1996). Verfahren der Perspektivenabschottung und ihre Auswirkung auf die Dynamik des Argumentierens. In W. Kallmeyer (Ed.), Gesprächsrhetorik. Rhetorische Verfahren im Gesprächsprozess (pp. 191-278). Tübingen: Narr.

Keim, I. (1999). Herstellen von Dominanz im Gespräch durch Dominantsetzen von Perspektiven. In J. Fohrmann, I. Kasten \& E. Neuland (Eds.), Autorität der/in Sprache, Literatur, Neuen Medien. Vorträge des Bonner Germanistentages 1997. Bd. 1 (pp. 110135). Bielefeld: Aisthesis.

Keim, I. (in press). Perspectivity and professional role in verbal interaction. In C. F. Graumann \& W. Kallmeyer (Eds.), Perspectivity and Perspectivation in Discourse. Amsterdam: Benjamins.

Kienpointner, M. (1996). Vernünftig argumentieren. Reinbek bei Hamburg: Rowohlt.

Klein, W. (1981). Logik der Argumentation. In P. Schröder \& H. Steger (Eds.), Dialogforschung (pp. 226-264). Düsseldorf: Schwann.

Nussbaumer, M. (1995). Argumentation und Argumentationstheorie. Heidelberg: Julius Groos.

Pander Maat, H. (1984). Argumentation: Zur Charakterisierung und Abgrenzung eines Forschungsgegenstandes. Studium Linguistik, 16, 1-20.

Patzelt, W. (1987). Grundlagen der Ethnomethodologie. München: Fink.

Perelman, C. (1980). Das Reich der Rhetorik. München: Beck.

Perelman, C., \& Olbrechts-Tyteca, L. (1958). La nouvelle rhétorique: traité e l'argumentation. Bruxelles: Ed. de l'Inst. de Sociologie.

Schegloff, E., \& Sacks, H. (1973). Opening up closings. Semiotica, 8, 289-327.

Schmitt, R. (1997). Unterstützen im Gespräch. Zur Analyse manifester Kooperationsverfahren. Zeitschrift für Sprachwissenschaft, 16(1/2), 52-82.

Schröder, P. (1995). Schlichtungsgespräche. Ein Textband mit einer exemplarischen Analyse. Berlin and New York: de Gruyter.

Searle, J. (1971). Sprechakte. Ein sprachphilosophischer Essay. Frankfurt a.M.: Suhrkamp

Spranz-Fogasy, T. (1986). 'widersprechen' - Zu Form und Funktion eines Aktivitätstyps in Schlichtungsgesprächen. Eine gesprächsanalytische Untersuchung. Tübingen: Narr. 
Spranz-Fogasy, T. (1997). Interaktionsprofile. Die Herausbildung individueller Handlungstypik in Gesprächen. Opladen: Westdeutscher Verlag.

Spranz-Fogasy, T. (1999). Interactional resources of argumentation. In F. van Eemeren, R. Grootendorst, J. A. Blair \& C. A. Willard (Eds.), Proceedings of the Fourth International Conference of the International Society for the Study of Argumentation (University of Amsterdam, July 16-19, 1998) (pp. 761-763). Amsterdam: SicSat.

Spranz-Fogasy, T. (in press). Argumentieren als Verfahren der Sachverhaltsklärung. Mannheim: Ms.

Spranz-Fogasy, T. (2002). "Interaktionsorganisation als (meta-)kommunikative Ressource des Argumentierens”. In S. Bastian \& F. Hammer (Eds.), Argumentation und Metakommunikation. Tübingen: Stauffenburg, 11-25.

Touimin, S. (1958). The Uses of Argument. Cambridge: Cambridge University Press.

Wolf, R. (1999). Soziale Positionierung im Gespräch. Deutsche Sprache, 27(1), 69-94.

Appendix. Transcription conventions

$\begin{array}{ll}{[\ldots]} & \text { omissions } \\ (\ldots) & \text { incomprehensible } \\ , * * & \text { micropause } \\ : & \text { lenghtening } \\ n & \text { emphasis } \\ , & \text { breaking off }\end{array}$

